\title{
Humanistic Design, and Beyond
}

\section{Giuseppe Lotti}

Università degli Studi di Firenze

giuseppe.lotti@unifi.it

ORCID 0000-0002-8066-5998

\begin{abstract}
The pandemic is consequence of our mistaken relationship with nature. It is crucial to learn from past mistakes and it is necessary to create a horizon of meaning for our thought and our action, centred on the health of the Planet, with man as an integral part of nature.

The design can contribute: a Humanistic design, based on a civil commitment, that works with the territories, in a cosmopolitan spirit, with an inclusive project; but also a design which, however, goes beyond Humanism, which takes away the central role of man - an anthropocentrism that through the ages has created numerous problems - in the name of a new accord, in harmony with nature as a whole.

The Francesco Faccini, Maurizio Montalti, Gionata Gatto, Giovanni Innella and Formafantasma's designs can be a possible example of this new idea.
\end{abstract}

\section{Keywords}

Environmental

and social crisis

Humanistic design

Nature

Restorative design 


\section{Pandemic and Crisis of the Development Model}

The events of the past few months have put into question many of our certainties. Anyone - and perhaps there are more than we thought - who looked at progress with unlimited faith has had to reconsider his positions; globalisation has many advantages, but also its fair share of risks; and Covid-19 has underlined the need for a radical revision of paradigms.

The approach of those who interpret the pandemic as a consequence of our mistaken relationship with nature is correct; thus Pope Francis: "A Spanish proverb says: 'God always forgives, man sometimes forgives, but nature never forgives'. I do not know if this crisis is nature's revenge, but it certainly is its answer" (Francis as cited in Cozzolino, 2020). This is a consideration that is supported by various authors; for Jeremy Rifkin: "the error, let us call it this so as not to use more apocalyptic terms, is called climate change. Extreme events [...] arrive annually [...] And always involve the escape and disordered migration of men, animals and viruses: the latter hang desperately to other living beings in order to survive" (Rifkin, // mondo che sarà, 2020). And, more recently, Alessandro Baricco: "it is comforting to give oneself the time to slowly read the inscriptions that the Pandemic carries [...] regarding our being with the world. It was difficult to tell us in a more unambiguous manner that we had gone too far in our technique of dominion over the existent" (Baricco, 2021, p. 31). A concept that has found support at the scientific level by Clementi and Liotta: "Scientists have been warning for decades about the effects of climate change on public health [...] Global warming" increases the "dissemination of everything". "Degraded habitats host more viruses that can infect humans" (Liotta \& Clementi, 2020, pp. 46, 47, 79).

Everything is interconnected; the pandemic is part of a larger problem linked to the model of development. The Goals of the 2030 Agenda for Sustainable Development of the United Nations are there to remind us: the objectives in fact include the world's health (3. Good health and well-being), yet all points are closely interconnected and cannot be addressed individually.

How many, however, have truly understood this relationship? Even if scientists agree in this respect, how many people actually show an interest in science? How many go beyond a partial and hurried search for information? Moreover, the immediate urgency of the pandemic increases the risk of putting the environmental question aside. "Why have we forgotten Greta? [...] Because of Covid-19, because the pandemic is an enormous health, economic and social problem [...] the truth is that we are not mentally and emotionally capable of handling two problems at the same time [...] Solving one problem at a time will not work: we will rebuild the wrong system we had and when we will finally address the climate issue it will be too late" (Luna, 2020).

Furthermore, certain recent choices imposed by the sanitary emergency have opened new environmentally and socially worrisome scenarios: from the billions of face-masks and gloves used over these past months which have been dispersed in the environment and are hard to recycle, to the increase in the use of disposable dishware and cutlery in the catering business, and the return 
to the use of private motor vehicles as central to mobility, as a result of them being interpreted as a safer means of locomotion: "Social Distancing will mark the victorious return of the automobile" affirmed the President of BMW Italia Massimiliano Di Silvestre in 2020. It is also worth considering the ascendancy of multinational on-line retailers, with negative consequences from the point of view of transportation, the increase of disposable packaging, and the labour conditions of their employees.

During the first lockdown numerous voices were raised to point out the risks related to the difficulty — or to the lack of will — to understand the true causes of the pandemic and to learn from the lesson. "Covid-19 is not a black swan, but rather a phenomenon which can repeat itself in the future, under other forms, if our response is to return as quickly as possible to our previous life-styles" (Giovannini, 2020).

Pandemics have always constrained humans to break with the past and to imagine their world anew. This one is no different. It is a portal, a gateway between one world and another. We can choose to traverse it dragging with us the carcasses of our hatred, our prejudices, our greed, our databases, our old ideas, our dead rivers and smoggy skies. Or we can cross it with a lighter baggage, ready to imagine a different world. And to fight for it (Roy, 2020).

Today, at a distance of a few months, the feeling - or rather the certainty - is that we have learnt practically nothing. We are waiting to begin again in the same way as it was before, probably with the excitement of someone who has been deprived of something for a long time: "our fear is that the 'catastrophe' will not have a true critical effect. The impression is that there is a wish to return the world exactly to the way it was before", with the "suspension not taking on the meaning of detachment from which to start again, almost as in a rite of passage, of a rest for the earth, as in other cultures and other moments in time" (Aime et al., 2020, p. 12).

It is necessary instead to try to invert this tendency, driven by the awareness that, if we were capable of changing radically in the past, perhaps we will be able to do so again: "The lesson I would like us to learn from the Coronavirus health crisis is that, when faced with an immediately palpable danger, we were able to take appropriate action, freeing ourselves from old dogmas. Let us do the same in the case of the climate crisis before it blows up in our faces" (Hulot, 2020).

\section{Thinking About the Future}

It is thus necessary to have an idea of the future, while learning from past mistakes. It is necessary to create a horizon of meaning for our thought and our action, centred on the health of the Planet, with man as an integral part of nature. As Alessandro Baricco wrote: "We only know how to play with the black pieces: if fear" — immigrants, terrorism, the effects of the digital era, gluten - "does not make a first move, we do not develop a strategy" Instead, "we are alive for developing ideas, for building some form of paradise, for enhancing our gestures, for understanding one thing more each day, and completing creation, hopefully with some taste [...] there is a game going on that 
has been awaiting our move for a long time" (Baricco, // mondo che sarà, 2020).

We need to determine a new shared narrative that holds together the overcoming of the pandemic, a critical reflection on the contribution of technology, a greater awareness of the challenges presented by sustainability, and a rethinking of our development model.

First of all going beyond the power of the market, overcoming "The colonisation of the imaginary by the economy" (Latouche, 2020, p. 28). In the words of the former President of Uruguay, Pepe Mujica: "It is not a question of imagining ourselves back in the time of the cavemen, or of raising a monument to backwardness. Yet we cannot continue to be indefinitely governed by the market, we must begin to govern the market ourselves" (Mujica as cited in Aime et al., 2020, p. 145).

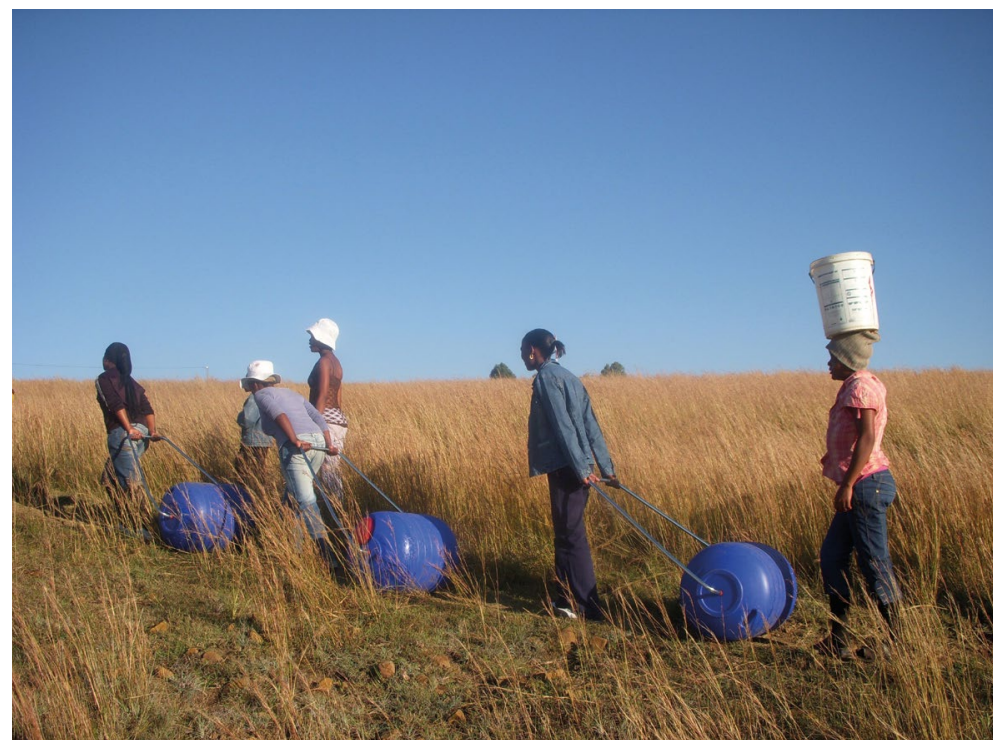

We must develop a conscious attitude towards technology, which too often is considered as an end rather than as a means, and must be oriented to the definition of the above-mentioned horizon of meaning. "What can we rely on? On technology perhaps? [...] Technology can be of great help, yet if technology acquires too much power over your lives you may end up by becoming a hostage to its agenda [...] Technology is not evil. If you know what you want in life, technology can help you obtain it. But if you do not know what you want from life, it would be all too easy for technology to shape your intentions and take control of your life" (Harari, 2020, pp. 349-351).

It is necessary to establish a new agreement with nature, in the awareness that man is not alone on the Planet, that all living beings are interdependent, that it is necessary to contrast the arrogance of the Anthropocene and that growth is not infinite. Examples abound. From Pope Francis, with his recent Encyclical (2020), to Greta Thunberg: "In fact, due to political inertia we have lost two
Pettie Petzer and Johan Jonker, Hippo water roller. 


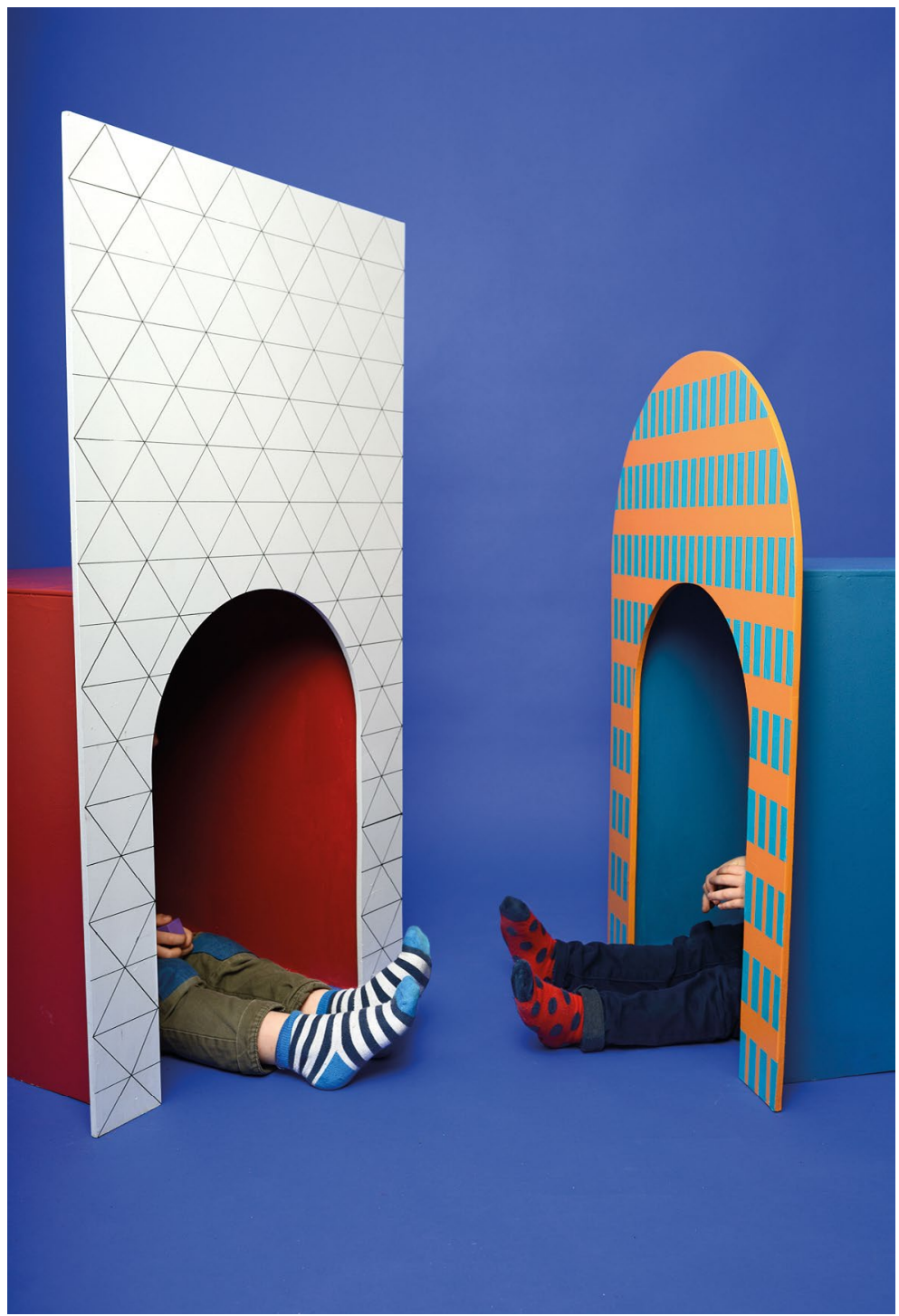

additional years of fundamental importance [...] We can no longer "continue to do business as usual [...] time is slipping through our fingers. We can still avoid the worst consequences, but in order to do so we must seriously address the climate emergency and change our lifestyle" (Thumberg et al., 2020). With environmental, socio-cultural and economic sustainability that can constitute the universe of meaning for technological innovation.

And then, surely more difficult to understand, and even more so to practice, yet not for this reason of less importance, we are in need of "a radical change in direction, a change in values, and to find or recover a certain sacredness (or intangibility) of the other, whether human or not" (Aime et al., 2020, p. 148). The ancient sacredness of nature, of places, of things, which protected them from 
the human actions. Pier Paolo Pasolini, more than forty-five years ago, although grasping all its ambivalence, had warned about the risks of the loss of the sacred in all of its manifold manifestations, and its replacement by a false sacredness of consumer goods dictated by mass media which, as a result of the incessant search for the new, leads to a permanent sense of dissatisfaction (Duflot, 1983; and more generally Pasolini, 2001). And Jaques Godbout, quoted by Latouche, "the artist reminds the modern individual that, whatever he may do, he is condemned to some form of animism if he wishes things to have meaning [...] 'animism is the only philosophy that respects things and the environment'" (Latouche, 2020, p. 83). Working in this way for a re-enchantment of the world, even through a new objective reality that is "denser" in terms of meanings and values.

\section{An Idea of Design}

The complexity of the challenges that we have before us require the contribution of several disciplines. The competencies of the humanities are decisive in this sense: "Since the multinationals and the entrepreneurs who lead the technological revolution naturally tend to sing the praises of their creations, it is the task of sociologists, philosophers and historians [...] to sound the alarm and to alert to all the ways in which things could take a nasty turn" (Harari, 2020, p. 12).

Equally important is the contribution of project-related disciplines at all scales, with design which, in recent years, has demonstrated, when compared to other fields, a superior ability to interpret reality and a greater speed of intervention.

A design that we could define as Humanist - recalling how Humanism and the Renaissance originated precisely at the end of the Black Death which struck Europe and Asia in the mid-14th century - taking from Humanism its general principles, updating them in light of the challenges which lie before us. A design based on a civil commitment; aimed to social concerns; that works in the territories and with the territories; through an interdisciplinary approach; creating a direct line with history and tradition as foundations for the new; in a cosmopolitan spirit of total cultural openness; with a participated, inclusive project; vindicating the social worth of work.

Italy has in this sense an important tradition, beginning with the experience of Adriano Olivetti - "Can industry have objectives? Are they simply in the profitability index? Is there nothing beyond the apparent rhythm, something in the life of a factory that is more fascinating, a destination, a vocation?" (Olivetti, 2012) - , to the concept of the socially responsible company, which does not consider the needs of the stakeholders exclusively, but rather the entire supply chain, the impact of production on territories, both near and distant, the sustainability of the development model, the respect for fundamental human rights, and the contribution to market civilisation. In the words of the economist Stefano Zamagni: "Today we know that the success of a business proceeds hand in hand with that of the territory to which it belongs" (Zamagni, 2013, p. 142). Values that can also be found in the design-related discourse: the importance of social networks, the balance between local and global, the "freedom" of makers and of shared making, the focus on the Global South, the 
valorisation of cultural heritage, the challenges of inter-culturalism. With the awareness that in the variability of solutions lies the correct approach to the complexity of the issues in question.

A design which, however, goes beyond Humanism, which takes away the central role of man - an anthropocentrism that through the ages has created numerous problems - in the name of a new accord, in harmony with nature as a whole.

All of which through a close link between ethics and aesthetics. With Italy which perhaps may, in this sense, play a particular role. "the world, at least the most developed countries [...] seem, albeit partially and slowly, to be moving towards a fairer economy [...] This is a dimension that leads to spaces, ways and forms that are greatly connected to the historical events related to the Italian style and its most outstanding results" (Benini, 2018, p. 254).

We find examples of this approach in Paola Antonelli's theoretical and critical reflection which found concrete expression in the Triennale's Broken Nature, with its focus on the environment and on the full awareness of the existing connection between the environment and social issues: "Until today, most of design was a powerful tool of the Anthropocene, with the human species solidly placed at its centre and human interests at the core of its objective" (Antonelli, 2019 , p. 19). "Design should be centred not only on humans, but also on the future of the biosphere" (Antonelli, 2019, p. 38). With consequent criticism to user-centred design which "can be easily considered as synonym of design centred on large businesses [...] design that is centred on the individual in fact reflects an old-fashioned and anthropocentric view of reality. It is time to remediate this with a good dose of altruistic and allocentric design" (Antonelli, 2019, p. 21). It is "the concept of restorative design" (Antonelli, 2019, p. 19).

This is an idea adopted by Marco Petroni as well, based on the awareness that we will never return to normality, because normality was the problem; to "Break definitely with the anthropocentric view of the world, with the disasters caused by the predatory mechanisms of capitalism, seems to be an unavoidable premise [...] The invitation is to consider our environment as a hyper-connected system in which humans are but a small part of an ensemble of multiple entities" (Petroni, 2020, p. 77).

\section{Going Beyond the Human-Centred}

From the point of view of the projects undertaken, it is worth mentioning Francesco Faccin's Honey Factory, a structure for producing honey in the city, with the "bees" that are "sentinels who keep watch over the health of the Planet, since their presence guarantees environmental well-being" (Dardi, 2015a). In the words of Faccin: "One can work on sustainability on various scales, my interventions are minimal, yet with great repercussions for people living mostly in urban contexts [...] There are many of us now working in this way [...] The strength of design is that it materialises a thematic, it provides concreteness" (Mascheroni, 2017). All of this without excessive illusions and in full awareness of the irreversibility of some changes: "We must accept the fact that we are living in a new dystopian world and seek alternative solutions without attempting to remedy what has 


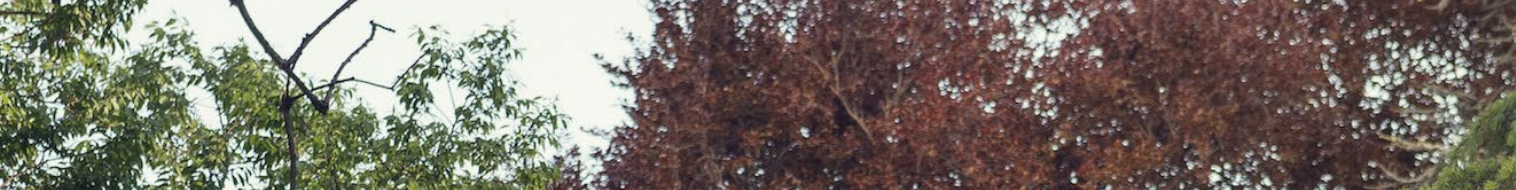

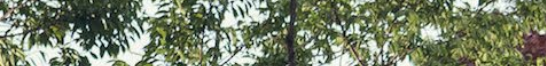
2.

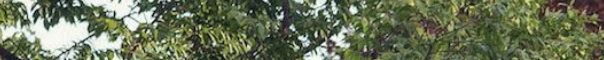

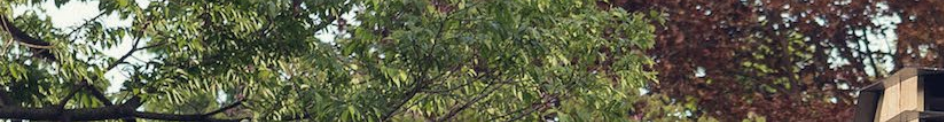

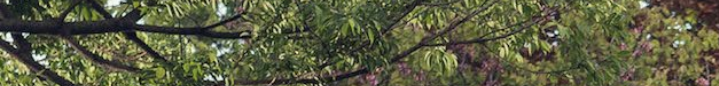
3.

H.

W

1. $\frac{1}{15}$

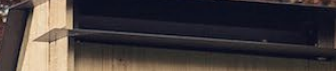

100,17020

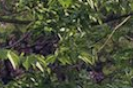

$2 \pi / 2$
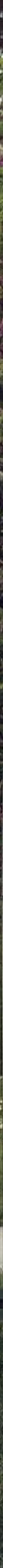
been destroyed, because it is not possible [...] the first question people ask me concerns the extinction of the bees, not how my beehive is made. This I like very much [...] like a snowball thrown from the top of a mountain, the Honey Factory could turn into an avalanche" (Mascheroni, 2017).

This is a concept retaken by Gionata Gatto, who speaks of "a new branch of design which assumes that also animal and plant species actively participate in a dialogue with our society" (Pacioli, 2017). For an increasingly hybrid nature which is "both vegetal and artificial. Technofossils plays with the impossibility of disentangling knots which result from natural and anthropogenic processes. Objects are also lights, refractions, leaves, chemistry, heat, multiplications, overlappings and wefts, unique and indivisible". The language of plants "Is a language which, although undecodable, is however adjacent to ours and should be somehow integrated so as to better understand the past and to design new 'possible futures'" (Pacioli, 2017).
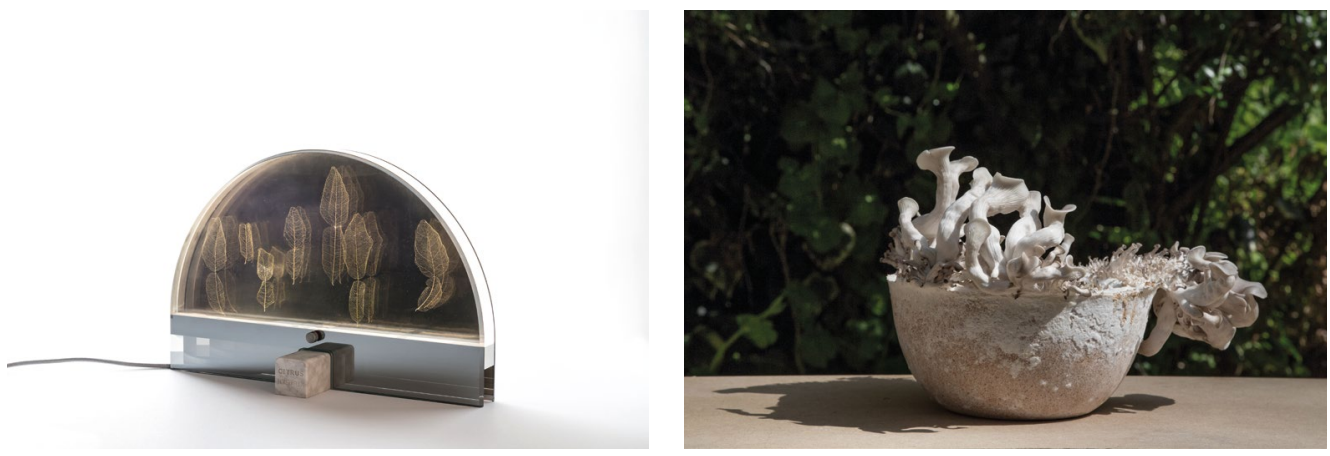

Maurizio Montalti's work with fungi aimed at the production of objects does not originate in the wish to use these microorganisms, but rather from the need to analyse the cycles of decomposition of natural materials: "fungi [...] are the great agents of natural transformation, the recyclers par excellence. Without them we would be submerged in rubbish [...] Furthermore, these fantastic microorganisms do not only feed on dead organic material, but are also capable of redistributing their components so as to create new life" (Dardi, 2015b). Regarding his process as researcher and designer: "At a certain moment I decided to question my situation due to the frustration which resulted from having to work with synthetic and polluting materials which had a very strong impact on the environment. I thus decided to devote myself to the identification of new alternatives derived from natural processes which could then be introduced in the market" (Colainni, 2017).

Regarding a work that requires an inter-disciplinary, or rather trans-disciplinary, approach, capable of holding together the contribution of both social and natural sciences, technology and the project - "I think there's no difference whatsoever between technology and biology. Biology is the ultimate form of technology by which we learn how to work with it, and not necessarily just to exploit it" (Schipper, 2019).
Officina Corp coli, Maurizio Montalti, The Growing Lab - Mycelia, bowl with fruiting bodies living.

Gionata Gatto, Tecnofossili. 


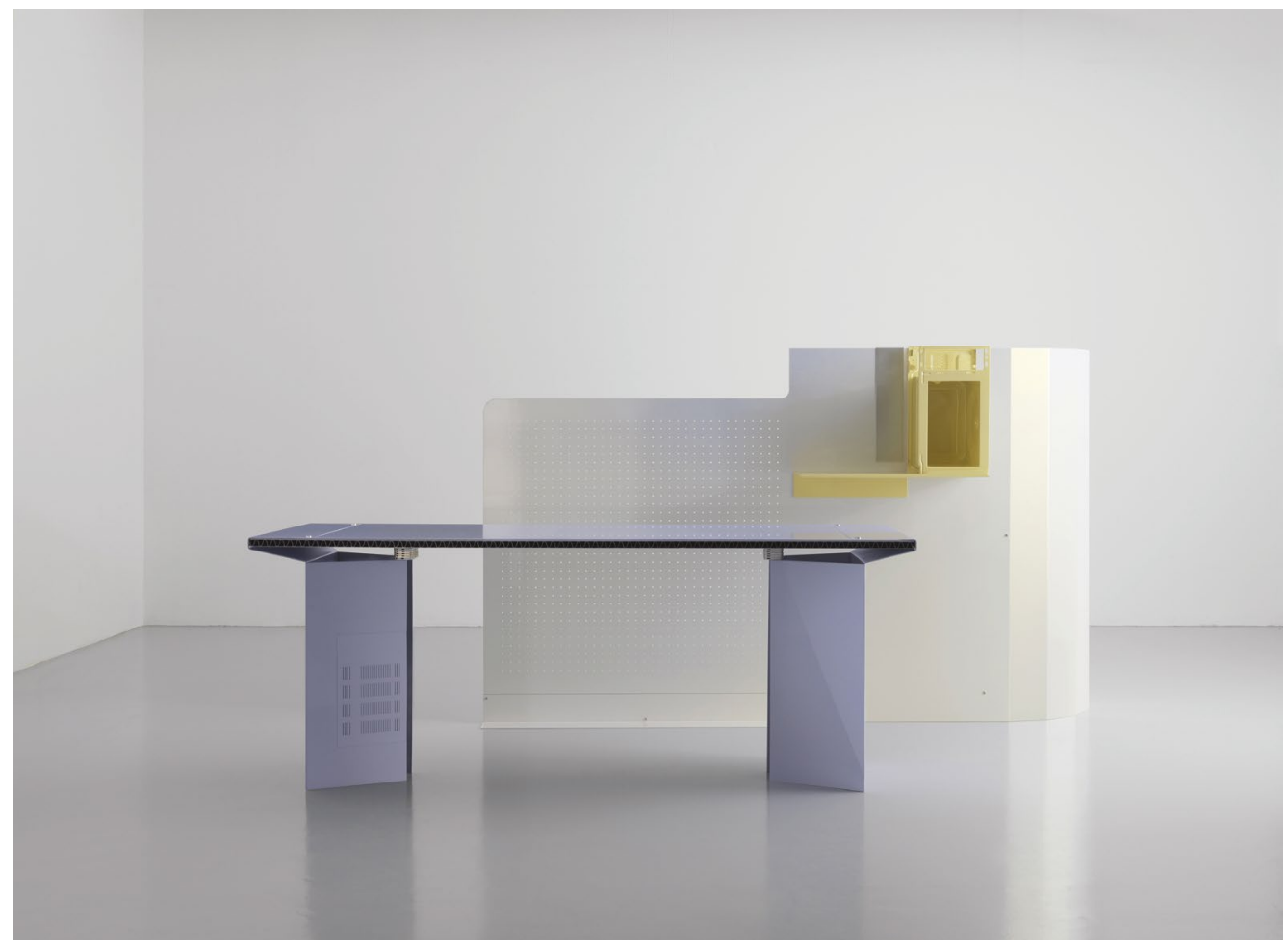

In these works it is easy to read a social, almost political approach: “I am an Utopian. And also an idealist. I don't believe one can hide behind the assumption that responsibility is always someone else's. I believe the designer must accept the responsibility of pointing out the limits of the industrial system and of its current production models" (Dardi, 2015b). In full awareness of the inevitable bias and of the risks of every proposal. "When one speaks of sustainability the public tends to imagine a perfect process, which uses zero energy and is completely 'neutral'. Unfortunately, both in artificial and natural systems, there is no process that is completely optimised or does not produce some form of waste [...] It is better to talk of ecological responsibility and of the need to understand how us humans are part of a very complex and articulated system. We are not separate from Nature" (Colainni, 2017).

In Formafantasma, which combines the Dutch experience at the Design Academy of Eindhoven - research plus conceptual design - with a typically Italian attention to aesthetics, we find what has been anticipated above, and especially a contribution to that deeper objectivity, laden with meaning, that borders on the magical, as referred to by Pasolini.

At the core of Formafantasma's research lies matter, whose presence is almost exalted: 'We let materials 'speak' and this is often a source of great worry, since the element of unpredictability present in them is very strong. The final result is never predictable from the beginning, in the same way that the 'ghost' form remains concealed until the end [...] the fascinating alchemical theme of the 
transformation of materials into gold" (Bordignon, 2014). Thus in De natura fossilium, a collection which uses the lava from mount Etna as its main production material, what is attractive is the changeability of the volcanic landscape, the energy of lava which is both destructive and constructive, its magical, primordial value.

In some of the studio's projects the attention to the themes of sustainability is more explicit, for example Autarchy - "a praise to simplicity and everydaness" (Ciuffi et al., 2010), is a collection of products made with a bio-material, and the colours are obtained from a selection of vegetables, spices and roots which are dried, boiled and filtered. In Ore Streams, commissioned by the Triennale di Milano for the exhibition Broken Nature, the focus is on the recycling of precious electronic waste for the production of a collection of office furniture built with recycled and no longer marketable materials; waste disappears in the overall, and almost abstract, balance of the composition.

On some occasions the focus on sustainability is broadened by addressing social implications, starting with the undergraduate thesis at the Design Academy of Eindhoven: Moulding Traditions - a study on North-African immigration and the melding of cultures in Sicily from the 17th century to the present, approached through a revisitation of the traditional production of ceramic Moor's heads.

In the works by Faccini, Gatto, Montalti and Formafantasma, design often takes on the features of critical design - speculative design. In the words of Giovanni Innella: "My path in the design practice draws from the critical approach of my research in the area of Design Critique. However, while my work in Design Critique questions the existing design industry, its trade and value, my design practice offers me a space where to be more constructive and propose alternatives. Pursuing my career as an independent designer, I keep on undertaking commissions or I initiate and propose projects to others. These projects are usually smaller and very diverse, privileging a strong conceptual approach" (Innella, n.d.).

The result is a hybrid design, very close to the world of art, which practices a great expressive freedom, non-commercial and with a strong conceptual emphasis; with the object which becomes one of the pieces in a more complex system that inquires into the capacity of designers to participate in the definition of new operational and conceptual areas of interest. Once again in the words of Petroni: in order to travel down this path "it is no longer necessary to wait for a commission, because the project in itself has the power to intervene in the present social, political and cultural transformations" (Giorgi, 2018). Design and president of the bachelor degree course in Industrial Design at the Università degli Studi di Firenze. He is scientific manager of research projects at European Union, national and regional level. $\mathrm{He}$ is the author of essays on project cultures and curator of exhibitions in Italy and abroad. 
Aime, M., Favole, A., \& Remotti, F. (2020). II mondo che avrete. Virus, antropocene, rivoluzione. Utet.

Antonelli, P., \& Tannir, A. (Eds.). (2019). Broken Nature. XXII Triennale di Milano. Electa.

Baricco, A. (2021). Quello che stavamo cercando. Feltrinelli.

Benini, R. (2018). Lo stile italiano. Storia, economia e cultura del Made in Italy. Donzelli.

Bordignon, E. (2014).

Formafantasma. De Natura Fossilium \#miart2014. ATP DIARY. http://atpdiary.com/ formafantasma-miart2014/

Ciuffi, V., Lardera, L., \& Silva, A. (2010, April 20). AUTARCHY by studio formafantasma. Abitare. https://www.abitare.it/ it/design/2010/04/20/ autarchy-by-studio-formafantasma/

Colainni, A. (2017). Design, scienza, arte: parliamo di

Officina Corpuscoli. Sapere Scienza. http://www. saperescienza.it/rubriche/ scienza-e-beni-culturali/ design-scienza-arte-parliamo-di-officina-corpuscoli/1676-design-scienza-arte-parliamo-di-officina-corpuscoli
Cozzolino, A. (2020). Papa Francesco e il coronavisus: "Dio perdona sempre, la natura mai". Corriere della Sera. https://www. corriere.it/pianeta2020/20_ aprile_11/papa-francesco-coronavirus-dio-perdona-sempre-natura-mai-8 17af4b8-7b44-11ea-afc6fad772b88c99.shtml

Dardi, D. (2015a). Honey Factory, Milano. Francesco Faccin. Klat. https:// www.klatmagazine.com/ design/honey-factory-milano-francesco-faccin-necessary-353/17635

Dardi, D. (2015b). Maurizio Montalti. "io sono un utopista". Klat. https:// www.klatmagazine.com/ design/maurizio-montalti-sono-un-utopista-interviews/16113

Duflot, J. (1983). // sogno del centauro/Pier Paolo Pasolini. Editori Riuniti.

Francis. (2020). Fratelli tutti. Enciclica sulla fraternità e l'amicizia sociale. Edizioni San Paolo.

Giorgi, E. (2018, July 7). Going Real, il nuovo libro di Marco Petroni, è un invito all'azione. Domus. https://www.domusweb. it/it/design/2018/07/07/ going-real-il-nuovo-libro-di-marco-petroni--un-invito-allazione.html

Giovannini, E. (2020, April 4). Covid 19 - riflessioni, previsioni e conseguenze economiche [Webinar]. Diplomatia. https://www. diplomatia.it/Multimedia/20200406/Diplomatia-GIOVANNINI.mp4
Harari, Y.N. (2020). 21 lezioni per il XXI secolo. GEDI.

Hulot, N. (2020, May 5).

L'ex ministro e i dissidenti sfidano Marcon: "Ora serve una svolta verde". La Repubblica. https://rep. repubblica.it/pwa/intervista/2020/05/09/news/ francia_nicolas_hulot_ambiente_intervista_e_cologie_de_mocratie_solidarite_-256194747/

I/ mondo che sarà. (2020). GEDI.

Innella, G. (n.d.). http://www. giovanniinnella.com/

Latouche, S. (2020). Come reincantare il mondo. La decrescita e il sacro. Bollati Boringhieri.

Liotta, E., \& Clementi, M. (2020). La rivolta della natura. La nave di Teseo.

Luna, R. (2020, August 8). Perché ci siamo dimenticati di Greta. La Repubblica. https://www.repubblica.it/ dossier/stazione-futuro-riccardo-luna/2020/08/31/ news/perche_ci_siamo_dimenticati_di_greta-265874546/

Mascheroni, L. (2017, December 14). Francesco Faccin: le sfide del design in una società distopica. Domus. https:// www.domusweb.it/it/ design/2017/12/13/francesco-faccin-le-sfide-del-design-in-una-societ-distopica.html

Olivetti, A. (2012). Ai lavoratori: discorsi agli operai di Pozzuoli e Ivrea. Edizioni di Comunità.
Pacioli, B. (2017, February 3). Gionata Gatto e la progettazione multispecie. La Repubblica. https://design. repubblica.it/2017/02/03/ gionata-gatto-e-la-progettazione-multispecie/

Pasolini, P.P. (2001). Scritti corsari. Garzanti.

Petroni, M. (2020). /I progetto del reale. // design che torna alla normalità. Postmediabooks.

Schipper, M. (2019). Maurizio Montalti talks nature's cycle of life. NNN. https:// nextnature.net/story/2019/ interview-maurizio-montalt

Thumberg, G., Neubauer, L., De Wever, A., \& Charlier, A. (2020, August 20). Greta Thumberg a Berlino L'incontro con Angela Merkel. 'Clima sfida globale'. La Repubblica. https://www. repubblica.it/dossier/ stazione-futuro-riccardo-luna/2020/08/31/news/ perche_ci_siamo_dimenticati_di_greta-265874546/

Zamagni, S. (2013). Impresa responsabile e mercato civile. II Mulino. 